\title{
Monitoring of caries disease by risk assessments and activity
}

\author{
Jenny ABANTO' \\ Gabriela Oliveira BERTI \\ Lucyene MIGUITA2 \\ Marcelo BONECKER ${ }^{1}$
}

\begin{abstract}
Dental caries is a non-communicable disease and is considered a public health problem. For diagnosis and correct treatment, the study of risk assessment and caries activity is necessary. The caries risk assessment is a way to formalize the balance and imbalance of predictably disease to diagnose dental caries. Therefore, the caries risk assessment is performed through different evaluation systems. Another parameter of great importance to be studied is the activity of caries, because through it is done the correct treatment decision for the patient. The objective of this article is to inform the reader about: the concepts and caries risk factors; the different caries risk assessment systems described in the literature; and which systems are validated. In addition, this literature review provides for identification and evaluation of risk factors and activity of caries lesions in order to enable greater objectivity in the diagnosis and facilitate the decisions of a successful treatment.
\end{abstract}

Indexing terms: Dental caries. Diagnosis oral. Risk.

\section{RESUMO}

A cárie dentária é uma doença não infecciosa e é considerada um problema de saúde pública. Para seu diagnóstico e correto tratamento é necessário a avaliação do risco e da atividade da doença cárie. A avaliação do risco de cárie é uma maneira de formalizar o equilíbrio e desequilíbrio da doença de modo previsível para realizar o diagnóstico da doença presente. Para tanto, a avaliação do risco de cárie é realizada através de diferentes sistemas. Outro parâmetro de grande importância a ser estudado é a atividade da doença cárie, pois através dela é realizada a correta decisão de tratamento para o paciente. Assim, o objetivo do presente artigo foi informar ao leitor: os conceitos e fatores de risco de cárie; os diferentes sistemas de avaliação de risco de cárie descritos na literatura; e quais sistemas são validados. Contudo, esta revisão de literatura proporciona a identificação e avaliação dos fatores de risco e atividade das lesões de cárie afim de possibilitar uma maior objetividade no diagnóstico e facilitar as decisões de um tratamento bem-sucedido.

Termos de indexação: Cárie dentária. Diagnóstico bucal. Risco.

\section{INTRODUCTION}

Dental caries is defined a non-communicable disease of slow progression that presents a dynamic character. It can be reversed at any time if the cause-effect relationship is modified in some manner ${ }^{1}$.

The prevalence of dental caries decreased among children in Latin America and the Caribbean ${ }^{2}$ countries. In Brazil, the dmf-t/DMF index decreased $13 \%$ and $26 \%$ in children aged 5 and 12 years, respectively, during the years 2003 to $2010^{3}$. Even so, tooth decay is still considered a public health problem affecting both developed and developing countries around the world ${ }^{4}$, resulting in a negative impact on quality of life among children ${ }^{5}$.
Among the factors involved in the process of caries the biofilm sugars have to be cited. The biofilm is the necessary factor for the development of the dental disease, however, its presence it is not enough if we considered that sugars is the determinant negative factor for development of dental caries ${ }^{6}$. At this respect, the caries risk can be decreased with the control of diet and guidance of hygiene, by reducing the consumption of sugar and regularly disrupting the biofilm ${ }^{6}$. The caries risk assessment (CRA) requires systems that include different factors or parameters to establish the likelihood of development of new dental caries lesions ${ }^{7}$. The effectiveness of the systems vary widely, depending on the number and type of factors/ risk indicators studied, clinical indicators of the disease

\footnotetext{
${ }^{1}$ Universidade de São Paulo, Faculdade de Odontologia, Departamento de Ortodontia e Odontopediatria. Av. Lineu Prestes, 2227, 05508-000, São Paulo, SP, Brasil. Correspondência para / Correspondence to: J ABANTO. E-mail: <jennyaa@usp.br>

${ }^{2}$ Universidade de São Paulo, Faculdade de Odontologia, Departamento de Patologia Oral e Maxilofacial. São Paulo, SP, Brasil.
} 
assessed $^{8}$, as well as the heterogeneity of populations studied, study design and analysis of data ${ }^{9}$. Currently, the CRA should aid the clinician in treatment decisions, recall intervals in dental office and even in the awareness of the patient and/or relatives ${ }^{8}$.

This article seeks to evaluate the concept and caries risk factors as well as the scientific evidence about the CRA systems/guidelines described more frequently in the international literature. Furthermore, consideration shall be held on the diagnosis of caries activity and how this affects the correct treatment decision.

\section{Concept and factors for caries risk}

The caries risk refers to the probability of an

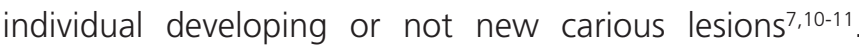
The risk factors are biological and/or the individual social factors that contribute to the increased risk of developing new caries in the future or progression of existing lesions (Figure $1 \mathrm{~A})^{12}$. It is of utmost importance to identify the factors and perform the CRA to determine the elements of the process to be controlled in order to improve oral health. In addition, it is known that the risk factors act in a combined manner, and their action is always greater than the simple arithmetic sum of related risks ${ }^{10,13}$.

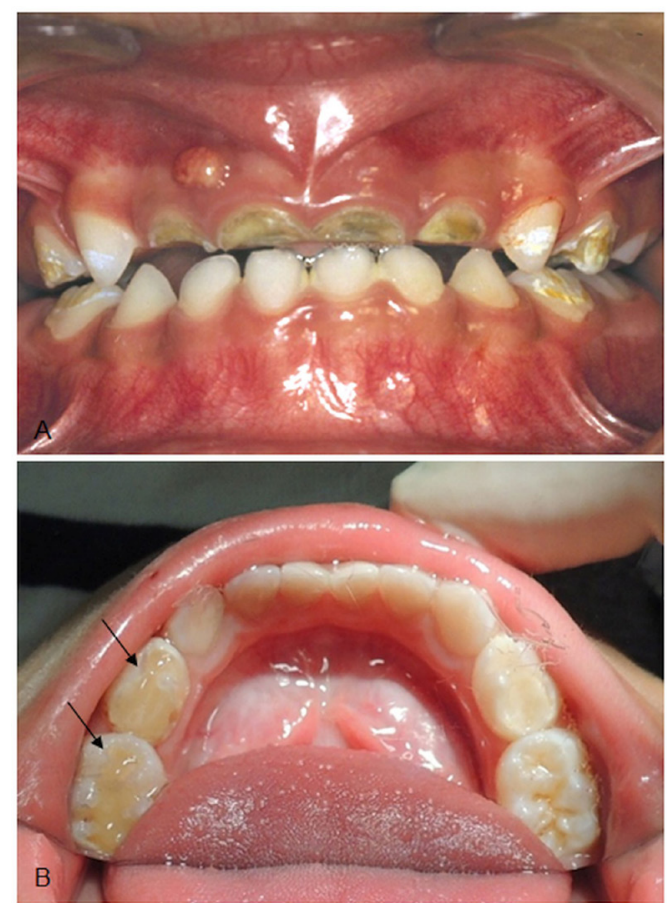

Figure 1. Clinical condition of existing caries lesion. A, children under 3 years of age with active and progressing caries lesions. B, children under 5 years of age with past experience of caries, considered more powerful predictor of caries in children. Arrows show restored low molar deciduous teeth.
The CRA is a way of formalizing the equilibrium and disequilibrium of the disease. It helps to predict future injuries, to determine the factors that are out of balance and it is necessary to reach a correct clinical decisions of evidence-based treatment ${ }^{14}$. The end result of any CRA is to match current clinical data and history of the patient. For this, the systems included some data such as the patient past experience of caries, socio-demographic, socioeconomic, oral hygiene and eating habits, and may include additional tests, such as saliva, $\mathrm{pH}$ and the bacterial load. All this will help establish the patient's caries risk and the level of activity of the disease (active or inactive caries lesions) $)^{9}$.

The factors considered to estimate the caries risk can be divided into two groups:

- Factors immediately involved and needed in the dental caries process: are factors of "attack" or mechanisms of "protection" in the evolution of the injury site. In the attacking factors, the sugars, the biofilm, the presence of bacteria in the biofilm and eating habits should be included. But when it comes to protective factors, salivary protection systems and exposure to fluoride should be considered.

- Factors related to the onset of caries without participation in the development of disease: for this group is considered various social factors as well as the past caries experience. Such factors may be designated as caries risk indicators, but are not required to occur the progression of the lesions.

A systematic review by Mejàre et al. ${ }^{9}$ evaluated the ability of multivariate models and individual factors to properly identify the development of new caries lesions in preschool and schoolchildren/adolescents. Among the individual factors, past experience of caries was the most powerful and accurate predictive factor at all ages for reflecting the caries activity in the past (Figure 1B). However, caries activity would be better reflected by methods that show the current metabolic activity in the biofilm. The counts of different bacterial species have been used for this purpose, but in general, its accuracy is poor. Eating habits, as individual factor, showed a predictive limited factor for all ages, although probably more significant in children with preschool age, since its fluoride exposure is limited to the use of a small amount of fluoridated toothpaste ${ }^{9}$. Despite this results, more recent evidence showed that sugars are the only cause of dental caries, all the other factors simply modify the speed of the cariogenic properties of sucrose ${ }^{15}$. Without sugars, the chain of causation is broken, so the disease does not occur ${ }^{15}$. 
Regarding the determinant and protective factors, another systematic review ${ }^{16}$ concluded that sugar intake is probably the most powerful indicator for risk of caries in people who do not have regular exposure to fluoride. This has been proven experimentally by showing that when fluoride toothpaste is not being used, an enamel demineralization occurs with only three exposures to sugar per day ${ }^{17-}$ 18. However, if the individual is regularly using fluoride toothpaste, this can reduce enamel demineralization of the sugar consumption when it is not greater than six times per day $^{19}$. On the other hand, sucrose consumed only twice a day changes the composition of the biofilm, increasing the risk for developing caries even if the person uses fluoride toothpaste ${ }^{19}$. Thus, the role of diet in the pathogenesis of the disease requires the assessment of dietary habits of the individual, the quality (type of carbohydrate - sucrose) and consistency of the diet (sugary foods, solid and sticky) to make the dietary advice ${ }^{21-22}$. Besides, the frequency of food intake is also an important information ${ }^{21}$. With the intake of carbohydrates, the $\mathrm{pH}$ of the biofilm decreases due to lactic acid production by Streptococcus mutans and Lactobacillus. This activity is interrupted by buffering system after 30-60 minutos ${ }^{21-22}$. When the carbohydrate intake frequency is high, pH levels of biofilm reduce promoting more dental demineralization ${ }^{21}$. Regarding the dietary advice, a randomized clinical study showed that guidance through home visits was effective in reducing early childhood caries $^{23}$. Then, interfere within factors that lead to the development of caries is fundamental, i.e., regularly disrupt the biofilm and reduce sugar consumption ${ }^{6}$.

Evidences showed that the period of greatest risk for the incidence of caries in permanent teeth were the first years after the tooth eruption ${ }^{9}$. As an alternative or complement to individual risk assessment, post-eruptive dental age could be used by considering all children at risk during the first years after dental eruption of permanent teeth.

The systematic review of Leong et al. ${ }^{24}$ focused on studies about the relationship between the acquisition/ colonization of cariogenic oral bacteria and early childhood caries, as well as about risk factors and/or protective factors for babies at 0 to 12 months old ${ }^{24}$. They confirmed that factors present during the first year of life affect early childhood caries experience. Despite the oral bacteria heterogeneity, the results indicated that there is an association between the acquisition of cariogenic oral bacteria in the baby and the levels of maternal bacteria. The cariogenic bacteria are a significant risk factor for caries in the first childhood ${ }^{24}$. However, the authors point that other factors such as eating habits, frequency and/or the type of food and fluid consumed by the baby are involved in colonization and the progression of the disease ${ }^{24}$. Moreover, the same authors reported that regular brushing with a dentifrice acts as a factor protection. Therefore, there is no scientific evidence to justify tracking oral bacteria such as mutans streptococci in babies ${ }^{25}$.

In this way, the results on the transmissibility of dental caries show that the vertical transmission (mother to child) cannot be controlled, because the transmission is not limited only by oral bacteria and, there is also horizontal transmission (other family members or baby surroundings). As fact, all babies acquire their environmental microbiota where they live, but once its microbiota is established, the bacteria of others do not implant in the resident oral cavity $^{6}$. So, it is much more significant to consider the hygiene habits and family diet incorporated in the child's routine and not the oral bacteria acquired, as they sooner or later will form part of the natural microbiota ${ }^{6}$.

In addition to the determining factors - individual, biofilm and diet - it is known that social, economic and behavioural factors can directly influence the prevalence of caries disease ${ }^{26}$. Studies have shown that the difference in health levels can be largely explained by differences in socioeconomic indicators and inequality levels in health ${ }^{20,27}$.

Another recently published study evaluated pre-existing systematic reviews covering the caries risk assessment in children ${ }^{28}$. Based on the findings, it concluded that caries risk assessment should be carried out in the child's first dental visit and reassessments should be done throughout childhood. Moreover, multivariate models of CRA exhibit better accuracy than the use of individual predictors, particularly in preschool children. However, there is no superior method, which forecast future caries, and there is no evidence to support the use of a specific model, program or existing technology for this purpose. Furthermore, from the child's caries risk should be carried out adequate care, preventive treatments and regular individual follow up appointment ${ }^{28}$.

It is important to remember that the risk of caries changes over time and needs to be reassessed in each follow up appointment ${ }^{12,29}$.

\section{Caries risk assessment systems}

In the international literature, the more often named and reported systems/guidelines are the CRA 
tool proposed by the American Association of Pediatric Dentistry ${ }^{30}$, the Management by Risk Assessment Philosophy (CAMBRA) advocated by the California Dental Association ${ }^{31}$, the American Dental Association (ADA) CRA forms ${ }^{32}$, and Cariogram ${ }^{33}$, a computerized program designed to simplify the CRA process with different weighting factors and interactions ${ }^{32}$. Recently, a new CRA tool developed by the Municipal Health of São Paulo (SMS) and adapted from the University of São Paulo (USP) was tested within a preventive program with promising results ${ }^{29}$.

At the present time, there is only evidence available on the prediction of caries for three of the four systems mentioned above. The evidence comes from cohort studies that report about caries predictive capacity of Cariogram, CAMBRA and SMS-USP.

Comparing different CRA systems, two systematic reviews ${ }^{8-9}$ evaluated if these systems were predictive of future caries. These systematic reviews have concluded that, in general, the scientific evidence on the validity of these systems for CRA is weak and limited, and no system has effective predictive utility of caries in children, especially for preschool age ${ }^{8-9}$. On these reports SMS-USP system was not included because it was recently published. However, the SMS-USP was described in the most recent systematic review of caries risk assessment tools as example of effectiveness of risk-based caries management models in children ${ }^{28}$

The Cariogram shown to be clinically useful to identify caries risk levels in the elderly, although it has limited usefulness in predicting CRA in children, especially in preschool age ${ }^{8-9}$.

On the other hand, the SMS-USP system presented himself as effective within a dental caries prevention program on reducing the incidence and promoting regression of initial caries lesions in children aged 1-12 years old ${ }^{29}$. On the study with SMS-USP system, the participant children were classified as low, moderate and high caries risk. It was observed that for each return visit, the risk of new initial caries lesions decreased by $77 \%$. Furthermore, the study showed that for every follow-up visit a child attended, the probability of him/her experiencing regression of active initial caries lesions significantly increased ${ }^{29}$.

High methodological design limitations on the CRA used in CAMBRA were found through a retrospective study ${ }^{34}$, which noted higher incidence of cavitated caries lesions among patients classified at high risk of caries compared to low risk ${ }^{34}$. Importantly, this study demonstrated no predictive ability of white spot lesions in contrast to studies using the Cariogram in which the risk of caries was a predictor of non-cavitated lesions. There is still an urgent need to develop valid and reliable methods for CRA that are based on the best scientific evidence from randomized clinical trials to predict and manage caries disease rather than experts' opinion ${ }^{8-9}$.

The following describes the Cariogram and SMSUSP systems in detail so that they can be applied as a basis for the oral health professional to discuss with the patient about different existing caries risk factors and to develop strategies for treatment and prevention of caries ${ }^{35}$.

\section{Cariogram}

The Cariogram ${ }^{\circledR}$ program ${ }^{36}$ is an interactive system for categorizing patients that shows through a chart the level of caries risk. It can be downloaded for free on internet in different languages using the website: http:// www.mah.se/fakulteter-och-omraden/Odontologiskafakulteten/Avdelning-och-kansli/Cariologi/Cariogram/. The Cariogram ${ }^{\circledR}$ parameters analyses the microbial factors, the intake frequency of diet, the carbohydrate content, past experience of caries, plaque amount, fluoride application, the buffer capacity of saliva and salivary flow rate. The combination of these factors determines the opportunity (probability) to avoid the appearance of dental caries or new lesions. Each of these elements is represented in a different colour, which facilitates the interpretation and identification of components that must be modified ${ }^{37-39}$. This software demonstrate graphically the risk of caries expressed as "The opportunity to prevent new caries lesions" in the near future. The CRA result is represented as a pie chart divided into five sectors, indicating the different groups of factors related to dental caries (see Figure 2). 


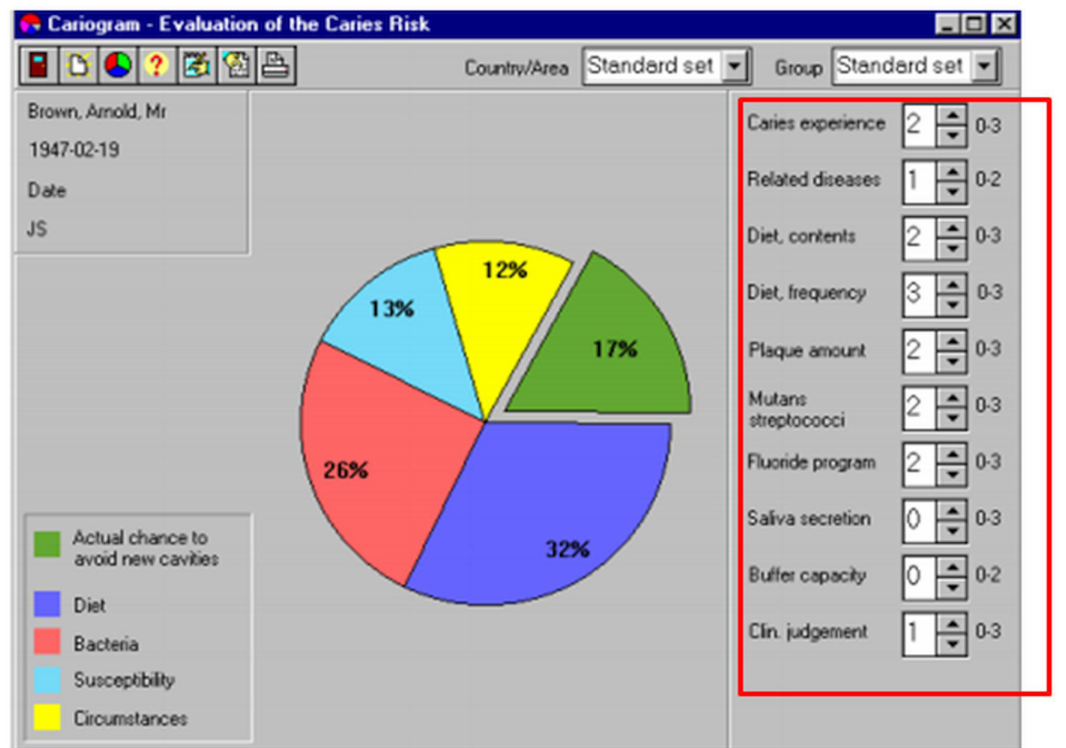

Figure 2. Programme's image showing the caries risk graph after analysis. Red line highlights the caries risk factors analysed by the program. Source: Adapted from Cariogram $\circledast$.

- The green sector (actual chance to avoid new cavities): shows an estimation of "real likelihood of avoiding new caries lesions" and "what is left" when other factors have taken their share. The "probability of avoiding new caries and the risk of caries" are topics for the same process but inversely expressed. When the probability to avoid new caries is high, the caries risk is small and vice versa, as shown below: High risk = low probability = small green sector; Low risk = high probability = big green sector.

- The dark blue sector (diet): is based on a combination of the amount of biofilm and Streptococcus mutans.

- The light blue sector (susceptibility): is based on a combination of fluoride use based on the information given by patients and / or guardians, the secretion of saliva and saliva buffering capacity.

- The yellow sector (circumstances): is based on a combination of past experience of caries and related diseases.

To interpret the chart, when higher the green sector, better the standpoint of oral health. When a narrow green sector is identified it means that there is high risk of caries. In other sectors, when the area marked on the graph is small, greater is indicative of good oral health ${ }^{40}$.

As seen, for the development of Cariogram $^{\circledR}$ graph is needed information about patient nutrition, caries experience, bacterial content, secretions and saliva buffer capacity. Despite its advantages, this system has as barriers to its use due to the additional cost of the query to require specific equipment and tests to fill the parameters analysed, limiting its use ${ }^{40}$.

\section{SMS-USP}

SMS-USP determines the recall intervals of patients according to their risk of caries, based on their oral clinical conditions, as detailed in Table 1. These oral conditions include the presence of biofilm, occurrence of gingivitis, caries experience and assessment of caries activity $^{41}$. Children are classified into five groups at risk of dental caries (A, B, C, D or E) and risk groups have different return intervals.

The recall interval of risk groups A (low risk), B and $\mathrm{C}$ (moderate risk) is determined every 12 months, while the recall interval for high risk patients, groups $D$ and $E$, is every 8 months and 4 months, respectively.

It is important to note that both caries risk groups $D$ and $E$ include active caries, however, the D-risk group consist of initial carious lesions, whereas in the caries risk group E consists of cavitated caries lesions.

The patients returned to their recall visits according to this classification, and during the follow-up exam the children are re-examined and their caries risk are re-classified, if necessary. It is important to mention that this CRA tool is applied for the public health system, and for this reason, recall intervals are spaced farther apart than would be commonly used in private clinical practice.

The oral clinical conditions on table 1 are evaluated according to different clinical criteria such as bleeding index ${ }^{42}$, plaque index and ${ }^{43} \mathrm{DMFT} / \mathrm{dmft}^{44}$. Initial carious lesions are evaluated according to ICDAS criteria. The activity of caries lesions is assessed according with the Lesion Activity Assessment (LAA) criteria ${ }^{46}$. The presence of plaque is determined by the plaque index and classified 
as fair or poor (scores of 1.0-3.0) and the clinical condition presence of gingivitis is determined by the gingival bleeding index and classified as mild to severe (values 0.1-3.0).

Table 1. Evaluation of the risk of caries and determination of return intervals. SMS-USP tool.

\begin{tabular}{|c|c|c|c|}
\hline Classification & Group & Clinical conditions & Recall interval \\
\hline Low risk & $A$ & $\begin{array}{l}\text { Absence of cavitated } \\
\text { caries lesions or } \\
\text { restored teeth, } \\
\text { without dental } \\
\text { plaque, without } \\
\text { gingivitis and/or } \\
\text { without active initial } \\
\text { caries lesions }\end{array}$ & Every 12 months \\
\hline \multirow[t]{2}{*}{ Moderate risk } & B & $\begin{array}{l}\text { Presence of restored } \\
\text { teeth. Absence of } \\
\text { dental plaque, } \\
\text { gingivitis and/or } \\
\text { absence of active } \\
\text { initial initial caries } \\
\text { lesions. }\end{array}$ & Every 12 months \\
\hline & C & $\begin{array}{l}\text { Presence of only } \\
\text { inactive caries lesions } \\
\text { associated with } \\
\text { absence of dental } \\
\text { plaque or gingivitis }\end{array}$ & Every 12 months \\
\hline \multirow[t]{2}{*}{ High risk } & $\mathrm{D}$ & $\begin{array}{l}\text { Presence of dental } \\
\text { plaque, gingivitis } \\
\text { and/or presence of } \\
\text { active initial caries } \\
\text { lesions associated } \\
\text { with absence of } \\
\text { cavitated caries lesion } \\
\text { or restored teeth }\end{array}$ & Every 8 months \\
\hline & $E$ & $\begin{array}{l}\text { Presence of one or } \\
\text { more active cavitated } \\
\text { caries lesion. }\end{array}$ & Every 4 months \\
\hline
\end{tabular}

\section{Caries activity concept}

The diagnosis of caries has changed over the years. Long ago, the most important part in the diagnostic process was only to detect the lesions, or simple recognition of the depth, regardless of the clinical features of the lesions. When caries lesion was found mainly in dentin, the treatment decision was the restoration ${ }^{20}$.

Studies show that it is also necessary to verify the clinical appearance of these lesions and through this make the best form of treatment and can often be the non-invasive treatment and monitoring of these carious lesions ${ }^{47-48}$. Thus, it is extremely important to check the activity of caries, the caries activity indicator shows us that the disease is present, i.e., presence of active lesions at the time of the clinical examination ${ }^{20}$. However, in a practical way, the caries activity is the manifestation of caries at that particular time, indicating that carious lesions are probably in progression.

Thus, the diagnosis of dental caries activity is essential for the treatment decision for each patient when properly evaluated favouring a better prognosis in the treatment of disease ${ }^{49}$. Regarding the treatment of inactive lesions (paralyzed), the only indication is the monitoring for the control and follow-up consultations. In the case of active lesions treatment is based on controlling the etiologic factors and surgical treatment and/or nonoperative, depending on the depth of the lesion (enamel or dentin).

\section{How to evaluate the activity of caries lesion?}

Considering the large number of risk factors described, the evaluation of the caries activity can become complex. It is correct to say that the actual activity of a carious lesion can be confirmed by actual progression (or not) over a given period of time. But some authors have proposed diagnostic criteria for evaluating caries activity by visual and tactile inspection by a "ball-ended point" or WHO probe passed smoothly over the tooth surface ${ }^{46,50-51}$.

To evaluate the lesion activity, some clinical parameters for expression of caries activity in the tooth surfaces have been associated ${ }^{52-53}$ : accumulation and/or biofilm retention potential; opacity associated with caries (brighter or dimmer); cavities, and depth of the lesion; texture (smooth or rough) and pigmentation of the lesion (white, yellow or blackened).

It is worth mentioning as extremely valid that all the features explained above reflect the carious lesion activity and its assessment as a whole is very important to make a correct diagnosis. Moreover, some studies show that prophylaxis prior to clinical evaluation of the activity is indicated by classifying each site according to their potential for biofilm accumulation, while other studies claim the examination of visible biofilm during the clinical examination ${ }^{46,54-55}$

To make the correct detection of the activity or not of carious lesion the professional can resort to the use of appropriate indexes, making this assessment less subjective ${ }^{46,50}$.

\section{Systems of Dental Caries Activity Assessment}

There are some validated systems of caries activity assessment (SCAA) that have been proposed by some researchers and used clinically:

(1) System Nyvad (NY) or Nyvad index (NY) ${ }^{50,56}$;

(2) The ICDAS-LAA (International Caries Detection and Assessment System - Lesion Activity Assessment) ${ }^{45,57}$.

The SCAA proposed by Nyvad takes into account the classification of lesions with intact surface, discontinuous surface and surfaces with cavities. And still 
ranks the injury as active or inative ${ }^{50,56}$. Thus, the Nyvad evaluation system demonstrated a good reliability ${ }^{50}$, as well as a good predictive validity for the evaluation of caries activity $^{56}$.

To standardize the caries detection procedures and describe more accurately the characteristics of the injury, a visual index for diagnosis of caries was proposed and is termed as ICDAS ${ }^{45}$. Recently, to be used in conjunction with ICDAS, a scoring system has been reported to the Lesion Activity Assessment (LAA), the ICDAS-LAA. Each LAA parameter observed in injuries is according to the predictive power of each parameter in the progression of lesion ${ }^{46}$. The ICDAS-LAA system proposes the sum of these points as a way of classifying these injuries on the caries activity $^{46}$. This system takes into account the pigmentation of the lesions, the severity, the accumulation potential and also the plate texture. ${ }^{58}$

Thus, in general, we considered that the lesion is active in enamel, when the enamel is opaque with whitish or yellowish discoloration, loss of gloss, rough surface when passing the probe and the lesion is located under biofilm accumulation region (pits and cracks, near the gingival margin, proximal surfaces below the contact point) ${ }^{46}$. The active lesions in dentin follows the same characteristics associated with softened dentin when the probe is passed over ${ }^{46}$.

\section{CONSIDERATIONS}

Regarding the monitoring of caries, two systematic reviews have shown that there is insufficient evidence coming from clinical trials to draw conclusions on the beneficial and harmful potential to alter the return intervals between dental visits ${ }^{59-60}$. Assuming that each child is an individual with different clinical conditions and treatment needs, this requires professional recall strategies and preventive care with differentiated treatment based on risk and caries activity.

It would then be possible to extend the recall intervals for children classified as low risk, and shorter recall intervals would be used for patients at higher risk

\section{REFERENCES}

1. Fejerskov O. Concepts of dental caries and their consequences for understanding the disease. Community Dent Oral Epidemiol. 1997;25(1):5-12. doi: 10.1111/j.1600-0528.1997.tb00894.x

2. Bönecker $\mathrm{M}$, Cleaton-Jones $\mathrm{P}$. Trends in dental caries in Latin American and Caribbean 5-6 and 11-13-year-old children: or need. At the level of public health, increasing the recall interval between consultations would offer a substantial saving of resources that could be used in other areas ${ }^{61}$. Although, there is no conclusive scientific evidence about the specific recall intervals for caries risk groups in children, the National Institute for Clinical Excellence (NICE), ${ }^{62}$ in 2004, issued a document (based on opinions of experts and a pre-existing systematic review) ${ }^{59}$, with recommendations on the most short and long return intervals between dental visits. This document depicts the shortest interval, between dental visits, for all patients should be three months, but no smaller than three months, unless if it is for specific reasons. This document also indicated that the longest interval between appointments for patients under 18 years-old should be 12 months ${ }^{62}$.

However, identify and assess the risk factors and characteristics of activity appropriately of caries lesions in appointments allows the clinician to decide the most appropriate treatment for the patient favouring their prognosis. In many cases, depending on the diagnosis of lesions or the progression of lesions, the clinician can choose more conservative treatments.

Regarding the treatment of inactive lesions (paralyzed) the only indication is the monitoring for the control and follow-up consultations, which the etiologic factors involved in the development of dental caries are evaluated. For active lesions treatment plan must be based on the control of etiologic factors and operative and nonoperative treatment, depending on the depth of the lesion (enamel or dentin). It is important to highlight that the control of etiologic factors in follow-up consultations are based on proper oral hygiene habits with regular use of fluoridated toothpaste, since the accumulation of biofilm on the tooth surface favours the appearance of new lesions and the progression of those already existing

\section{Collaborators}

All authors contributed to the bibliographical survey and to the conception, composition and to the final review of the article.

a systematic review. Community Dent Oral Epidemiol. 2003;31(2):152-7. doi: 10.1034/j.1600-0528.2003.00009.x

3. Brasil. Ministério da Saúde. Coordenação Nacional de Saúde Bucal da População Brasileira. Projeto SB Brasil 2010: resultados principais. Brasília (DF): Ministério da Saúde; 2011. [citado 2012 jan 11]. Disponível em: <http://189.28.128.100/dab/docs/geral/ projeto_sb2010_relatorio_final.pdf>. 
4. Vadiaskas G. Case definition, aetiology and risk assessment of early childhood caries (ECC): a revisited review. Eur Arch Paediatr Dent. 2008;9(3):114-5.

5. Abanto J, Tsakos G, Paiva SM, Carvalho TS, Raggio DP, Bönecker M. Impact of dental caries and trauma on quality of life among 5- to 6-year-old children: perceptions of parents and children. Community Dent Oral Epidemiol. 2014;42(5):385-94. doi: 10.1111/cdoe.12099

6. Tenuta LM, Chedid SJ, Cury JA. Uso de fluoretos em Odontopediatria - Mitos e evidências. In: Maia LC, Primo LG. Odontopediatria clínica integral. São Paulo: Santos; 2012.

7. Kidd EA. Assessment of caries risk. Dent Update. 1998;25(9):38590.

8. Tellez M, Gomez J, Pretty I, Ellwood R, Ismail A. Evidence on existing caries risk assessment systems: are they predictive of future caries? Community Dent Oral Epidemiol. 2013;41(1):6778. doi: 10.1111/cdoe.12003

9. Mejàre I, Axelsson S, Dahlén G, Espelid I, Norlund A, Tranæus S, Twetman S. Caries risk assessment. A systematic review. Acta Odontol Scand. 2014;72(2):81-91. doi: 10.3109/00016357.2013.822548

10. Krasse B. Biological factors as indicators of future caries. Int Dent J. 1988;38(4):219-25

11. Raitio M, Pienihakkinen $\mathrm{K}$, Scheinin A. Multifactorial modeling for prediction of caries increment in adolescents. Acta Odontol Scand 1996;54(2):118-21.

12. Young DA, Featherstone JDB. Caries management by risk assessment. Community Dent Oral Epidemiol. 2013;41(1):e5363. doi: 10.1111/cdoe.12031.

13. Anusavice KJ. Clinical Decision-Making for Coronal Caries Management in the Permanent Dentition. J Dent Educ. 2001;65(10):1143-6.

14. Featherstone JD. The caries balance: the basis for caries management by risk assessment. Oral Health Prev Dent. 2004;2(Suppl 1):259-64.

15. Sheiham A, James WP. Diet and Dental Caries: The Pivotal Role of Free Sugars Reemphasized. J Dent Res. 2015;94(10):1341-7. doi: $10.1177 / 0022034515590377$

16. Burt BA, Pai S. Sugar consumption and caries risk: a systematic review. J Dent Educ. 2001;65(10):1017-23.

17. Cury JA, Rebello MA, Del Bel Cury AA. In situ relationship between sucrose exposure and the composition of dental plaque. Caries Res. 1997;31(5):356-60.

18. Duggal MS, Toumba KJ, Amaechi BT, Kowash MB, Higham SM. Enamel demineralization in situ with various frequencies of carbohydrate consumption with and without fluoride toothpaste. J Dent Res. 2001;80(8):1721-4. doi: 10.1177/002203450108000808

19. Ccahuana-Vásquez RA, Tabchoury CP, Tenuta LM, Del Bel Cury AA, Vale GC, Cury JA. Effect of frequency of sucrose exposure on dental biofilm composition and enamel demineralization in the presence of fluoride. Caries Res. 2007;41(1):9-15. doi: $10.1159 / 000096100$
20. Bonecker M, Rocha R, Rodrigues CRMD. Cariologia. In: GuedesPinto AC, Bönecker $M$, Rodrigues CRMD. Fundamentos de odontologia: odontopediatria. São Paulo: Santos; 2009. p. 13345.

21. Wanderley MT, Tashima AY. Hábitos Alimentares. In: GuedesPinto AC, Bönecker $M$, Rodrigues CRMD. Fundamentos de odontologia: odontopediatria. São Paulo: Santos; 2009. p. 183202.

22. Lorenzo JL, Lorenzo A. Etiologia de cárie dental: base da prevenção atual. In: Cardoso RJA, Gonçalves EAN. Odontopediatria: prevenção. São Paulo: Artes Médicas; 2002. p. 215-34.

23. Feldens CA, Vítolo MR, Drachler Mde L. A randomized trial of the effectiveness of home visits in preventing early childhood caries. Community Dent Oral Epidemiol. 2007;35(3):215-23. doi: 10.1111/j.1600-0528.2006.00337.x

24. Leong PM, Gussy MG, Barrow SY, de Silva-Sanigorski A, Waters E. A systematic review of risk factors during first year of life for early childhood caries. Int J Paediatr Dent. 2013;23(4):235-50. doi: 10.1111/j.1365-263X.2012.01260.x

25. O'Keefe E. Early childhood caries. Evid Based Dent 2013;14(2):40-1. doi: 10.1038/sj.ebd.6400928

26. Narvai PC, Frazao P, Roncalli AG, Antunes JL. Dental caries in Brazil: decline, polarization, inequality, and social exclusion. Rev Panam Salud Publica. 2006;19(6):385-93.

27. Antunes JL, Jahn GM, de Camargo MA. Increasing inequalities in the distribuition of dental caries in the Brazilian context in Finland. Community Dent Health. 2005;22(2):94-100.

28. Twetman S. Caries risk assessment in children: how accurate are we? Eur Arch Paediatr Dent. 2015 Jul 19. [Epub ahead of print]. doi: 10.1007/s40368-015-0195-7

29. Abanto J, Celiberti P, Braga MM, Vidigal EA, Cordeschi T, Haddad $A E$, et al. Effectiveness of a preventive program based on caries risk assessment and recall intervals on the incidence and regression of initial caries lesions in children. Int J Paediatr Dent. 2015;25(4):291-9. doi: 10.1111/ipd.12144

30. American Academy of Pediatric Dentistry Council on Clinical Affairs. Policy on use of a caries-risk assessment tool (CAT) for infants, children and adolescents. Pediatr Dent. 2008-2009;30(7 Suppl):29-33.

31. Featherstone JD, Domejean-Orliaguet $S$, Jenson L, Wolff $M$, Young DA. Caries risk assessment in practice for age 6 through adult. J Calif Dent Assoc. 2007;35(10):703-13, 710-3.

32. American Dental Association Caries Risk Assessment Forms [online]. 2011 [citado 2014 Mar 28]. Available from: <http:// www.ada.org/sections/professionalResources/pdfs/topics_ caries_instructions.pdf>.

33. Bratthal D, Hänsel Peterson G. Cariogram: a multi-factorial risk assessment model for a multifactorial disease. Community Dent Oral Epidemiol. 2005;33(4):256-64. doi: 10.1111/j.16000528.2005.00233.x

34. Domejean S, White J, Featherstone J. Validation of the CDA CAMBRA caries risk assessment -a 6 year retrospective study. J Calif Dent Assoc. 2011;39(10):709-15. 
35. Sánchez Pérez L, Acosta Gio AE, Méndez Rámirez I. A cluster analysis model for caries risk assessment. Arch Oral Biol. 2004;49(9):719-725. doi:10.1016/j.archoralbio.2004.02.012

36. Gao XL, Hsu CY, Xu Y, Hwarng HB, Loh T, Koh D. Building caries risk assessment models for children. J Dent Res. 2010;89(6):63743. doi:10.1177/0022034510364489

37. Petersson GH. Assessing caries risk-using the Cariogram model. Swed Dent J Suppl. 2003;(158):1-65.

38. Hänsel Petersson G, Fure S, Bratthall D. Evaluation of a computerbased caries risk assessment program in an elderly group of individuals. Acta Odontol Scand. 2003;61(3):164-171.

39. Petersen PE. Sociobehavioural risk factors in dental caries international perspectives. Community Dent Oral Epidemiol. 2005;33(4):274-9. doi: 10.1111/j.1600-0528.2005.00235.x

40. Melgar RA, Acosta J, Flores M, Flores M, Gonzáles B, Heredia C. Bases para una prevención efectiva. Colegio Odontológico del Perú: Comisión Nacional de Salud Bucal del Colegio Odontológico del Perú; 1998.

41. Secretaria Municipal da Saúde de São Paulo. Diretrizes para a Atenção em Saúde Bucal - Crescendo e vivendo com saúde bucal: http://www.prefeitura.sp.gov.br/cidade/secretarias/upload/ saude/arquivos/sau-debucal/Diretrizes_Saude_Bucal_2012.pdf

42. Silness J, L€oe $\mathrm{H}$. Periodontal disease in pregnancy. Response to local treatment. Acta Odontol Scand. 1966;24(6):747-759.

43. Greene JC, Vermillion JR. The simplified oral hygiene index. J Am Dent Assoc. 1964;68:7-13

44. WHO. Oral Health Surveys: basics methods. 4th ed. Geneva: World Health Organization; 1997

45. Ismail Al, Sohn W, Tellez M, Amaya A, Sen A, Hasson H, et al. The International Caries Detection and Assessment System (ICDAS): an integrated system for measuring dental caries. Community Dent Oral Epidemiol. 2007;35(3):170-8. doi: 10.1111/j.16000528.2007.00347.x

46. Ekstrand KR, Martignon S, Ricketts DJ, Qvist V. Detection and activity assessment of primary coronal caries lesions: a methodologic study. Oper Dent. 2007;32(3):225-235. doi: $10.2341 / 06-63$

47. Ekstrand KR, Christiansen ME. Outcomes of a non-operative caries treatment programme for children and adolescents. Caries Res. 2005;39(6):455-67. doi:10.1159/000088180

48. Maltz M, Barbachan e Silva B, Carvalho DQ, Volkweis A. Results after two years of non-operative treatment of occlusal surface in children with high caries prevalence. Braz Dent J. 2003;14(1):4854.

49. Nyvad B. Diagnosis versus detection of caries. Caries Res. 2004;38(3):192-8. doi:10.1159/000077754

50. Nyvad B, Machiulskiene $\mathrm{V}$, Baelum $\mathrm{V}$. Reliability of a new caries diagnostic system differentiating between active and inactive caries lesions. Caries Res. 1999;33(4):252-60. doi: $10.1159 / 000016526$
51. Braga MM, Martignon S, Ekstrand KR, Ricketts DN, Imparato JC, Mendes FM. Parameters associated with active caries lesions assessed by two different visual scoring systems on occlusal surfaces of primary molars - a multilevel approach. Community Dent Oral Epidemiol. 2010;38(6):549-58. doi: 10.1111/j.16000528.2010.00567.x

52. Nyvad B, Fejerskov O. Assessing the stage of caries lesion activity on the basis of clinical and microbiological examination. Community Dent Oral Epidemiol. 1997;25(1):69-75. doi: 10.1111/j.1600-0528.1997.tb00901.x

53. Ekstrand KR, Ricketts DN, Kidd EA. Reproducibility and accuracy of three methods for assessment of demineralization depth of the occlusal surface: an in vitro examination. Caries Res. 1997;31(3):224-31

54. Ekstrand KR. Improving clinical visual detection--potential for caries clinical trials. J Dent Res. 2004;83(Spec No C):C67-71. doi: $10.1177 / 154405910408301$

55. Ismail Al. Visual and visuo-tactile detection of dental caries. J Dent Res. 2004;83(Spec No C):C56-66. doi: $10.1177 / 154405910408301 S 12$

56. Nyvad B, Machiulskiene $V_{1}$ Baelum V. Construct and predictive validity of clinical caries diagnostic criteria assessing lesion activity. J Dent Res. 2003;82(2):117-22. doi: $10.1177 / 154405910308200208$

57. Pitts N. "ICDAS"--an international system for caries detection and assessment being developed to facilitate caries epidemiology, research and appropriate clinical management. Community Dent Health. 2004;21(3):193-8.

58. Braga MM, Mendes FM, Ekstrand KR. Detection activity assessment and diagnosis of dental caries lesions. Dent Clin North Am. 2010;54(3):479-93. doi: 10.1016/j.cden.2010.03.006

59. Davenport CF, Elley KM, Fry-Smith A, Taylor-Weetman CL, Taylor RS. The effectiveness of routine dental checks: a systematic review of the evidence base. Br Dent J. 2003;195(2):87-98. doi: 10.1038/sj.bdj.4810337

60. Riley P, Worthington HV, Clarkson JE, Beirne PV. Recall intervals for oral health in primary care patients. Cochrane Database Syst Rev. 2013;12:CD004346. doi: 10.1002/14651858.CD004346. pub4

61. Riordan PJ. Can organized dental care for children be both good and cheap? Community Dent Oral Epidemiol. 1997;25(1):119125. doi: 10.1111/j.1600-0528.1997.tb00908.x

62. National Collaborating Centre for Acute Care (UK). Dental Recall: Recalllnterval Between Routine Dental Examinations. London: National Collaborating Centre for Acute Care (UK); 2004.

Received on: 18/6/2015 Final version resubmitted on: 27/9/2015 Approved on: 13/11/2015 